\title{
Land cover change in western Madagascar's dry deciduous forests: a comparison of forest changes in and around Kirindy Mite National Park
}

\author{
Amanda S. Whitehurst, Joseph O. Sexton and Luke Dollar
}

\begin{abstract}
Western Madagascar's dry forests have suffered greater levels of deforestation than the island's humid eastern forests, and many of the largest remaining contiguous tracts of dry forest are conserved in Kirindy Mite National Park. To assist Kirindy Mite's management plan, we assessed land cover change in and around the Park, remotely sensing forest cover within the Park and an arbitrary 5-km buffer from Landsat images taken in 1990, 2000 and 2006. We then quantified forest cover and change and compared the values between the Park and buffer, interpreting the results through expert knowledge of the area. Kirindy Mite had lower rates of deforestation, higher rates of reforestation, and less net change than the unprotected zone in both 1990-2000 and 2000-2006. Park deforestation rates were approximately one third to one fourth those of the buffer, and Park reforestation rates were approximately double those of the buffer. Net change in the Park fluctuated between the two periods, with deforestation during 2000-2006 slightly exceeding reforestation during 1990-2000. All land cover changes accelerated over the study period, and disturbances in the Park were most frequent near its boundary. To maintain the forest as differences in forest cover across the Park boundary increase, we suggest including or intensifying measures to: (1) expand the Park boundary, simplifying its shape, (2) cooperate with the local people in managing a buffer zone, and (3) increase monitoring to minimize anthropogenic disturbances crossing the Park boundary.
\end{abstract}

Keywords Deforestation, dry forest, Kirindy Mite, Landsat, Madagascar, reforestation.

\section{Introduction}

adagascar is one of the world's top biodiversity con1 servation priorities because of its high concentration of endemic species and extreme rates of habitat loss. The endemic species of Madagascar comprise 3.2 and $2.8 \%$ of plant

AMANDA S. Whitehurst* (Corresponding author), Joseph O. SeXTON and Luke Dollart Nicholas School of the Environment, Duke University, Durham, NC, USA. E-mail amanda.whitehurst@gmail.com

${ }^{*}$ Current address: University of Maryland, Department of Geography, College Park, Maryland 20742, USA.

${ }^{\dagger}$ Also at: Pfeiffer University, Department of Biology, Misenheimer, North Carolina, USA.

Received 6 October 2007. Revision requested 8 January 2008. Accepted 4 March 2008. and vertebrate animal species, respectively (Myers et al., 2000). Madagascar's primary vegetation has decreased to 9.9\% of its original extent (Myers et al., 2000), severely fragmenting native habitats throughout the island (Green \& Sussman, 1990). Forest fragmentation exacerbates the loss of faunal diversity as well, because remaining forest patches are often too small to support viable populations (Ganzhorn et al., 2000; Ramanamanjato, 2000). Ganzhorn et al. (2001) predicted that continued degradation of the western dry forests will render the remaining fragments incapable of supporting viable populations by 2040 but even this may be an optimistic projection of the island's viability (Dollar, 2006).

The primary drivers of Madagascar's forest degradation are subsistence agriculture and small-scale tree harvest (Raugh, 1979; Sussman et al., 1985; Jenkins, 1987; Green \& Sussman, 1990). In western Madagascar forests and savannahs are burned by farmers to clear land for crops or by nomadic tribes whose cattle prefer young grasses. Selective tree harvests occur to extract wood for charcoal production, harvest high-value species such as rosewood and palissandre (Dalbergia spp.) or collect honey (Dollar, 2006). Although national parks and reserves protect some areas from deforestation, illegal harvest reduces forest cover considerably (Ganzhorn et al., 2001).

Over $97 \%$ of Madagascar's dry deciduous forests have been lost (WWF, 2001), and the remnants have become so fragmented that, even in the larger forested areas, species are increasingly and almost universally affected by human influences (Ganzhorn et al., 2001). However, conservation of the dry deciduous forests of western Madagascar has been relatively ignored compared to that of the eastern humid forests (WWF, 2001).

Overcoming these problems requires a combination of conservation research and social change (Ganzhorn et al., 2001). One potential solution to deforestation is to provide local communities with improved agricultural techniques and other means of earning a living (Green \& Sussman, 1990; Sussman et al., 1994), such as participation in ecotourism. Reforestation, whether natural or anthropogenic, can also be a key tool in preventing or reversing species losses (Ramanamanjato \& Ganzhorn, 2001). After disturbance, regrowing forests remain in transitional, secondary stages for decades (Aide et al., 2000), meanwhile providing a subset of the ecosystem services supplied by mature, intact forest (Costanza et al., 1997; Barlow et al., 2007a).

Kirindy Mite National Park is one of the largest areas of protected dry forest in Madagascar and contains some of the 
largest remaining contiguous tracts of dry forest. The Association Nationale pour la Gestion des Aires Protégées (ANGAP) plans to expand the Park to increase the amount of protected forest, especially in areas where risk of species extirpations is high, and to stimulate research and ecotourism in the region. Western Madagascar lags behind the island's humid east in acquiring the data necessary to implement successful conservation and management plans (Ramanamanjato \& Ganzhorn, 2001). To assist these plans we made a thorough assessment of land cover change in and around the Park using a time series of satellite images and expert knowledge of the region. We quantified forest cover, change, and acceleration of change from 1990 to 2000 and 2006. We then compared these values between the Park and a $5-\mathrm{km}$ buffer zone of unprotected land around the Park's perimeter arbitrarily demarcated for the purpose of analysis. We evaluated effectiveness of the Park's forest preservation by comparing the changes in the Park to those in the buffer and suggest specific actions to benefit both Madagascar's dry forests and local communities.

\section{Study area}

Kirindy Mite National Park is located in the dry deciduous forest region of western Madagascar, in the Toliary (Tuléar) Province c. $60 \mathrm{~km}$ south-west of Morondava (Fig. 1). A group of 11 small villages lies just beyond $10 \mathrm{~km}$ eastsouth-east of the Park, and four villages occur near the coast to the west of the Park, three of which are within the Park's boundary. Legal logging operations occurred within the Park in the 1980s but the location and degree of harvest is unknown. No planting or other artificial reforestation is known to have occurred in the area.

The region's climate exhibits a dry season from April to early November and a hotter, rainy season during the remainder of the year. The forests senesce phenologically in response to water stress and remain dormant during the dry season. Fauna include $>55$ species of birds, 65 species of reptiles and amphibians, and 31 species of mammals, including eight species of lemur (Butler, 2005; Dollar, 2005).

This study focuses on the potentially forested areas of the Park and an arbitrary 5-km buffer outside the Park boundary (Fig. 1). This buffer width was slightly less than half the shortest distance to the permanent villages south-east of the Park. The total area examined in this study, both within the Park and buffer, is 140,087 ha, determined by digitizing and excluding major river beds, salt flats, and coastal/tidal areas from the satellite images. These excluded areas in the Park and buffer either do not contain forest or the forest patches therein are too isolated or small to be relevant to study or management action. Exclusion of these areas decreased the study area within the Park from 86,736 ha to 78,868 ha. Excluding salt flats and coastal areas, the buffer comprised 61,219 ha.

\section{Methods}

\section{Data preparation}

Satellite image data were taken from the Landsat Thematic Mapper (TM) and Enhanced Thematic Mapper Plus (ETM+) sensors in Path 161 Row 74 of World Reference System 2 (WRS2). We acquired the 10 July 1990 TM image and the 21 June 2000 ETM+ image from the Global Land Cover Facility (GLCF, 2006) and purchased the 26 June 2006 ETM+ image from the United States Geographic Survey (USGS, 2007) EROS Data Center. Because of the Scan-Line Correction malfunction of ETM+ on the 2006 image, missing data were interpolated with phenologically similar images from 27 May 2006, 13 September 2005, 9 August 2004 and 16 July 2002.

To increase precision among multiple sensors and image dates, all three images were geometrically rectified to the 2000 image $(<30 \mathrm{~m}$ root mean squared error $)$ and converted to surface reflectance. The 1990 TM image was converted to radiance using the conversion for Level 1 products of Chander \& Markham (2003), and the 2000 and 2006 ETM+ images were converted using the methods of Williams (2007). Surface reflectance was estimated from the radiance images by simple dark object subtraction (Song et al., 2001).

\section{6 land cover classification}

We mapped current land cover within the study area by Maximum-Likelihood supervised classification (Jensen, 1996) of the 2006 ETM+ image. Three vegetation classes were defined along the study area's vegetation gradient: bare ground, savannah (including anthropogenic grasslands with sparse woody vegetation) and forest (including both primary and secondary types). One hundred and thirty-one training points were collected, consisting of 64 forest and savannah ground-truth points taken in summer 2006 and 67 photointerpreted points of forest, savannah and bare ground cover determined by examining 2007 aerial photographs accessed via Google Earth (Google Earth, 2007). Spectral signatures were estimated from Bands 3, 4, 5 and 7 (i.e. red, nearinfrared, short wave infrared and long wave infrared) surface reflectances of the $2006 \mathrm{ETM}+$ image. To reduce apparent anomalies in the 2006 image and avoid horizontal atmospheric variation, Bands 1 (blue) and 2 (green) were not used in the classification.

\section{Change detection}

We converted the 1990, 2000 and 2006 images to binary maps of forest/non-forest cover by thresholding the Normalized Difference Vegetation Index (NDVI; Rouse et al., 1973; Jensen, 1996) calculated from the surface reflectances. Primary and secondary forest types are difficult to distinguish 


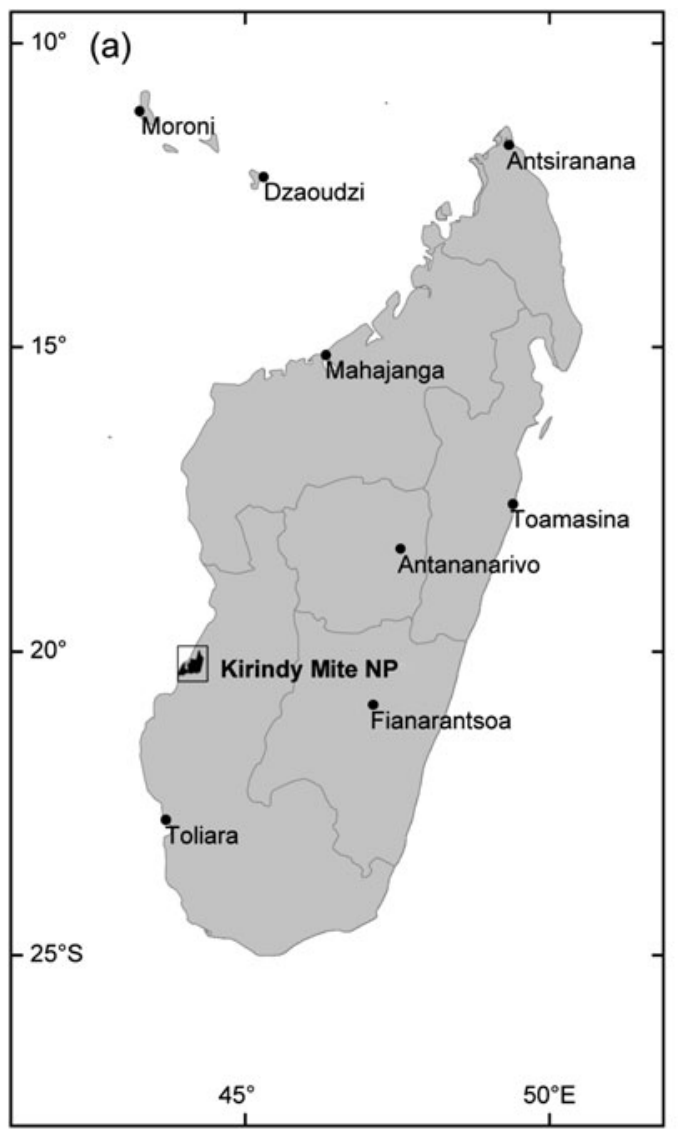

(b)

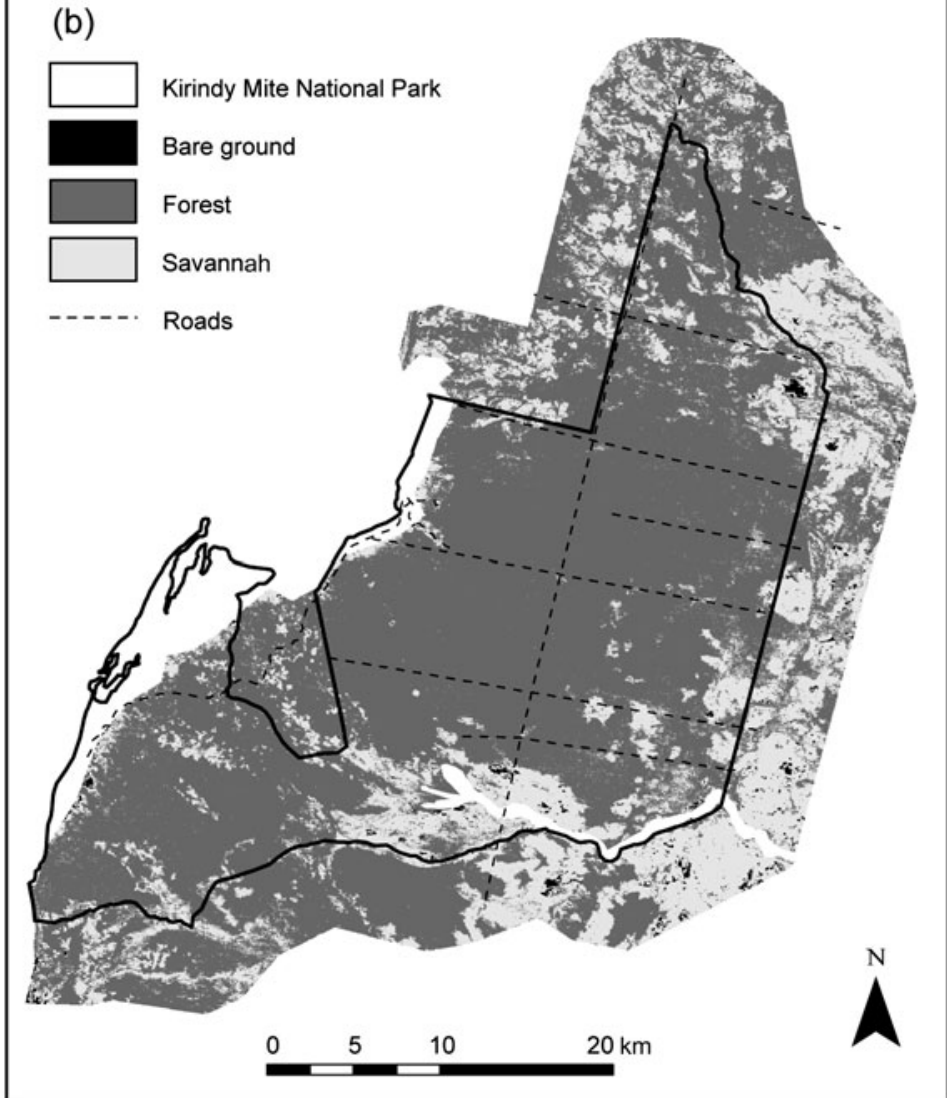

Fig. 1 (a) Location of Kirindy Mite National Park in western Madagascar, and (b) 2006 land cover estimated by Maximum-Likelihood satellite image classification (see text for further details).

in Landsat images, even within a single image date (Green \& Sussman, 1990; Harper et al., 2007). Therefore, despite the sacrifice of detail regarding intermediate types in the continuum from forest to non-forest (i.e. savannah, degraded and secondary forest), a binary classification was chosen to avoid imprecise spectral signatures and minimize spurious land cover changes resulting from phenological differences between images. Whereas the 4-band MaximumLikelihood classification provided greater accuracy for a single time, NDVI was used for change detection because the red and near-infrared bands used to calculate it optimize sensitivity to vegetation cover with insensitivity to atmospheric noise between images, thereby allowing more reliable map comparisons over time. Use of radiometrically and atmospherically corrected surface reflectances, as opposed to raw brightness values, further enhanced this precision. A single NDVI threshold of 0.232 was applied to all the images to discriminate forest (which included areas of woodland and dense savannah) from non-forest (which included areas of sparse savannah). This threshold was chosen and verified visually through histograms and maps, the former by a clear separation between two independent modes of the NDVI distribution and the latter by correspondence to known and photo-interpreted forest and non-forest patches.
Forest and non-forest percentages of the total area of the Park and buffer were tabulated for each year and then the maps of forest cover were overlain to examine changes in forest cover over the periods 1990-2000 and 2000-2006. Deforestation events were identified as per-pixel changes from forest to non-forest and reforestation as changes from nonforest to forest in the binary classification. All reforestation detected by this analysis is natural, as no anthropogenic reforestation activities have occurred in this area over this period. Deforestation was tallied for the Park and buffer as percentages of forest area at the beginning of each interval (i.e. 1990 for the 1990-2000 interval). Likewise, reforestation within the Park and buffer were tallied relative to the respective areas of non-forest at the beginning of each interval. Rates of deforestation (\% lost per year) and reforestation (\% gained per year) were calculated by dividing these percentages by the number of years in the respective interval. Incorporating both deforestation and reforestation, net forest change in the Park and buffer were tallied as differences in forest cover from the beginning to the end of each interval, expressed as percentages of Park and buffer areas. Subtracting the $1990-2000$ rates $\left(\% \mathrm{yr}^{-1}\right)$ from the 2000-2006 rates and dividing by the 16-year span of the study provided estimates of acceleration of forest gain, loss, and net change in units of $\% \mathrm{yr}^{-1} \mathrm{yr}^{-1}$, or $\% \mathrm{yr}^{-2}$. 
A continuous-scale or sub-pixel analysis was also performed to locate areas of minor forest disturbance. NDVI images were paired for the periods 1990-2000, 2000-2006 and 1990-2006, and differences between early and late images were examined for evidence of minor deforestation events such as small fires or selective harvest. Whereas the categorical nature of the previous analyses removed phenological variability at the expense of sub-pixel information, retention of phenological noise limited this analysis to visual inspection.

\section{Results}

\section{6 land cover classification}

In 2006 the study area (both Park and buffer) was predominantly vegetated (Fig. 1), with 101,031 ha $(72 \%)$ forest and 38,165 ha $(27 \%)$ savannah (Table 1). Much less of the area (892 ha, $<1 \%)$ was covered by bare ground, which mostly comprised recently burned land but also well-traveled dirt roads. The Park was more heavily forested than the buffer, with 66,167 forested hectares (84\%) in the Park compared to 34,864 ha $(57 \%)$ of forest in the buffer. Subject to greater burning pressure, the buffer had 25,764 ha (42\%) of savannah compared to the Park's 12,402 ha (16\%). The amount of bare ground was similar, with 300 ha $(<1 \%)$ of bare ground in the Park and 592 ha (1\%) of bare ground in the buffer.

\section{Change detection}

Phenological variability between image years required a separate land cover classification for change detection. Therefore, in this analysis 'forest' refers broadly to dense savannahs and woodlands as well as fully canopied forests, and 'nonforest' refers to sparse savannahs as well as herbaceous and bare areas. Thus defined, the area covered by forests decreased over the study period in both the Park and buffer but losses were greater and more persistent outside the Park (Table 2). Within the Park the forested area increased slightly from 76,991 ha $(97.6 \%)$ in 1990 to 77,592 ha (98.4\%) in 2000 but decreased to 76,869 ha $(97.5 \%)$ in 2006 . In contrast, the buffer's forested area decreased from 57,329 ha (93.7\%) in 1990 to 54,836 ha (89.6\%) in 2000 and decreased again to 52,593 ha $(85.9 \%)$ in 2006 , with non-forested area

TABLE 1 Vegetation cover of Kirindy Mite National Park and arbitrary $5-\mathrm{km}$ buffer around the Park in 2006, estimated by Maximum-Likelihood satellite image classification.

\begin{tabular}{lccc}
\hline & Park, ha (\%) & Buffer, ha (\%) & Total, ha (\%) \\
\hline Forest & $66,166.6(83.89)$ & $34,864.1(56.95)$ & $101,030.7(72.12)$ \\
Savannah & $12,401.7(15.72)$ & $25,763.7(42.08)$ & $38,165.4(27.24)$ \\
Bare & $300.0(0.38)$ & $591.5(0.96)$ & $891.5(0.64)$ \\
Total & $78,868.3$ & $61,219.3$ & $140,087.6$ \\
\hline
\end{tabular}

more than doubling from $6.4 \%$ in 1990 to $14.1 \%$ in 2006 . Because of the change in classification ontology, forest/ non-forest estimates for the Park in 2006 varied between the two classification schemes: 78,568 ha $(99.6 \%)$ of forest from Maximum-Likelihood classification compared to 76,869 ha $(97.5 \%)$ of forested area (forest and dense savannah) from the NDVI thresholding of the change detection analysis. This reflects the different spectral sensitivities of the classifications as well as their different thresholds of savannah tree density.

Kirindy Mite National Park had lesser rates of deforestation, greater rates of reforestation, and less net change than the buffer in both time periods (Table 2). Deforestation occurred in both the Park and buffer in each period but rates in the Park were $25-33 \%$ of those in the buffer. In contrast, reforestation was also evident in both the Park and buffer in both periods but rates in the Park were approximately double those in the buffer. In the Park net change switched from gain to loss between the two periods, with minor reforestation from 1990 to 2000 slightly more than offset by deforestation from 2000 to 2006. Net change in the buffer was negative and on average 4-5 times the magnitude of changes in the Park in either period.

All changes in both the Park and the buffer accelerated from 1990 to 2006 (Table 2). Rather than indicating deceleration of absolute change, negative acceleration of net changes showed that deforestation increased faster than reforestation in both the Park and buffer from 1990 to 2006. Reforestation rate increased in both areas but the acceleration in the Park was c. 7.5 times that of the buffer. In contrast, acceleration of deforestation in the buffer was c. 1.7 times that of the Park.

Deforestation and reforestation varied over the study area (Fig. 2). Most changes were in regions dominated by savannah in 2006 (Fig. 1). Whereas the Park's core remained mostly forested and undisturbed from 1990 to 2006, a large non-forested region persisted in the south-east corner of the buffer, between the Park and the nearby villages. In both the 1990-2000 and 2000-2006 time periods major forest losses were concentrated in the south-east of the study area and scattered throughout the buffer. From 2000 to 2006 losses decreased in the south-east and shifted to the north, flanking and increasingly crossing over the boundary into the Park. Many of the disturbances apparently initiated in the buffer penetrated into the Park, often stopping at or just beyond the Park boundary (Fig. 2). In the first period reforestation (including significant re-establishment of woody vegetation cover) occurred primarily in a recently burned savannah around the river-bed in the south-eastern corner of the Park. In the later period, much of this area was again deforested, whereas reforestation was more evenly distributed in small patches around the Park and buffer.

Sub-pixel analysis revealed a location of slight but unusual vegetation loss in 2000-2006, near the eastern boundary of 
TAвLE 2 Area and changes in forest cover (including dense savannah/woodland) in Kirindy Mite National Park and an arbitrary 5-km buffer in 1990, 2000, and 2006.

\begin{tabular}{|c|c|c|c|c|c|c|}
\hline & Park & & & Buffer & & \\
\hline Forested area & 1990 & 2000 & 2006 & 1990 & 2000 & 2006 \\
\hline $\mathrm{Ha}$ & $76,990.6$ & $77,592.0$ & $76,869.0$ & $57,328.9$ & $54,835.6$ & $52,593.3$ \\
\hline$\%^{1}$ & 97.62 & 98.38 & 97.47 & 93.65 & 89.57 & 85.91 \\
\hline Change & & $1990-2000$ & $2000-2006$ & & $1990-2000$ & 2000-2006 \\
\hline Gain $\left(\% y^{-1}\right)^{1}$ & & 8.40 & 11.39 & & 4.96 & 5.36 \\
\hline Loss $\left(-\% y^{-1}\right)^{2}$ & & 0.13 & 0.34 & & 0.57 & 0.92 \\
\hline Net $\left(\% y^{-1}\right)^{3}$ & & 0.08 & -0.15 & & -0.41 & -0.61 \\
\hline Acceleration & & & 1990-2006 & & & 1990-2006 \\
\hline Gain $\left(\% y^{-2}\right)$ & & & 0.19 & & & 0.03 \\
\hline Loss $\left(-\% y^{-2}\right)$ & & & 0.01 & & & 0.02 \\
\hline Net $\left(\% \mathrm{yr}^{-2}\right)$ & & & -0.01 & & & -0.01 \\
\hline
\end{tabular}

${ }^{1}$ Relative to bare area at beginning of interval

${ }^{2}$ Relative to forest area at beginning of interval

${ }^{3}$ Relative to total area

the Park (Fig. 3). This linear disturbance bisected a forested area, extending in a line parallel to the Park boundary and perpendicular to a major Park road, and was met by a pair of larger disturbances that crossed the Park boundary from the savannahs of the buffer region. The disturbance's shape, orientation, and proximity to the Park boundary, as well as the connection to the savannah, all suggest human action, possibly cattle-driving through the Park.

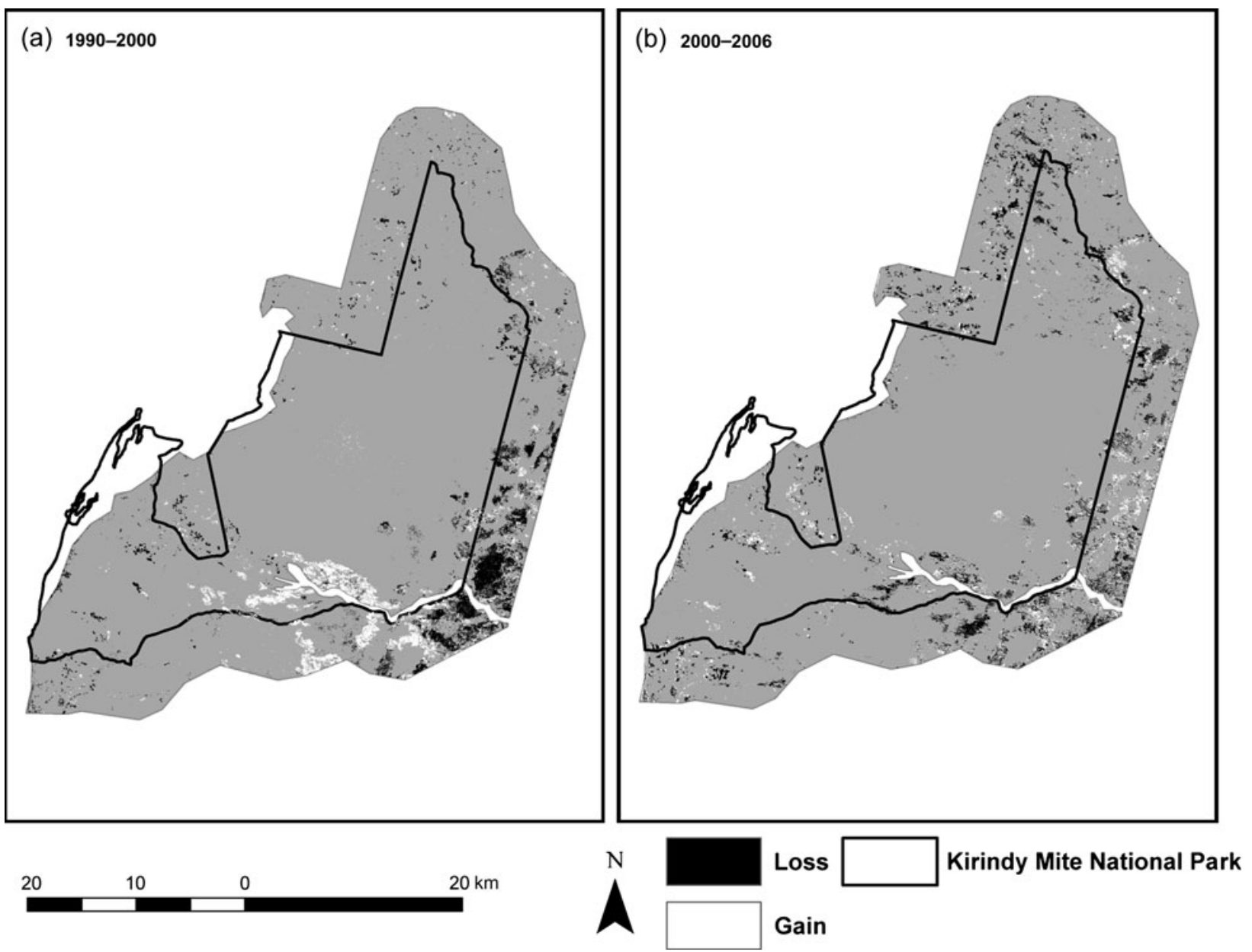

FIG. 2 Deforestation and reforestation within Kirindy Mite National Park and an arbitrary 5-km buffer from 1990 to 2000 (a), and from 2000 to 2006 (b). 

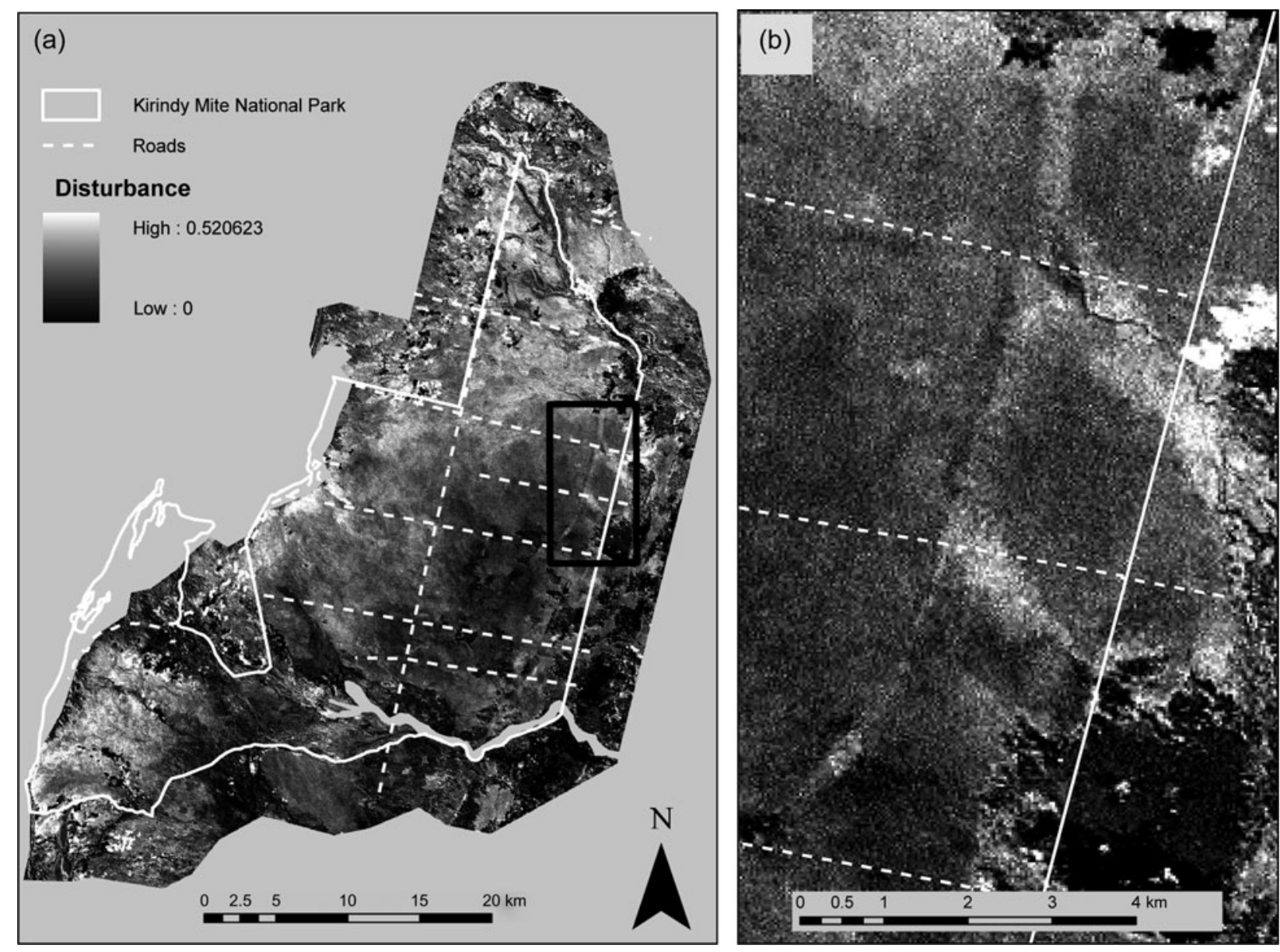

FIG. 3 (a) Disturbance crossing the Park boundary between 2000 to 2006, detected by NDVI subtraction (see text for further details), and (b) magnified to show detail.

\section{Discussion}

\section{Park effectiveness}

Kirindy Mite National Park appears to be effectively conserving its portion of Madagascar's dry deciduous forest in an environment of increasing human impact. Albeit in absence of strict counter-factual evidence, this conclusion is supported by two observations: (1) differences in forest change between the Park and buffer and (2) the spatial pattern of deforestation relative to the Park boundary. Since 1990 the Park has sustained a higher percentage of forest cover, lower rates of deforestation, and higher rates of reforestation than the unprotected area outside the Park's boundary. Such differences could be attributable either to influence of the Park or to its relative inaccessibility. However, the apparent avoidance of the Park by the spread of deforestation suggests a significant Park influence. Although most of the early (1990-2000) deforestation occurred around the villages in the south-east of the Park and buffer, the shift of later (2000-2006) deforestation to the north remained outside the Park boundary despite the fact that forests within the Park were more accessible to villages than the forests cleared in the buffer, via spatial proximity and Park roads.

Despite its favourable comparison to the unprotected buffer, deforestation slightly exceeded reforestation inside the Park, resulting in the Park's woody vegetation cover diminishing slightly $(<1 \%)$ over the study period. Assuming the average rates of change in the Park and buffer over the span of this study remain constant, the buffer will be reduced to $50 \%$ forest cover (including woodlands and dense savannahs) by 2080 while the Park's cover will remain $>96 \%$ (Fig. 4). However, if the acceleration of the past 16 years continues, the buffer will be reduced to $50 \%$ cover by 2047 , with the Park following in 2086. These projections extrapolate trends based on a small sample in time and ignore important aspects of the socio-ecological system, and therefore further analysis is needed to provide more confident forecasts. However, these implications are cause for concern.

Disturbances in Madagascar's dry forests are predominantly anthropogenic, mainly burning to create grazing areas for cattle, or cutting trees for commercial wood or charcoal production, or honey gathering (Dollar, 2006). The 


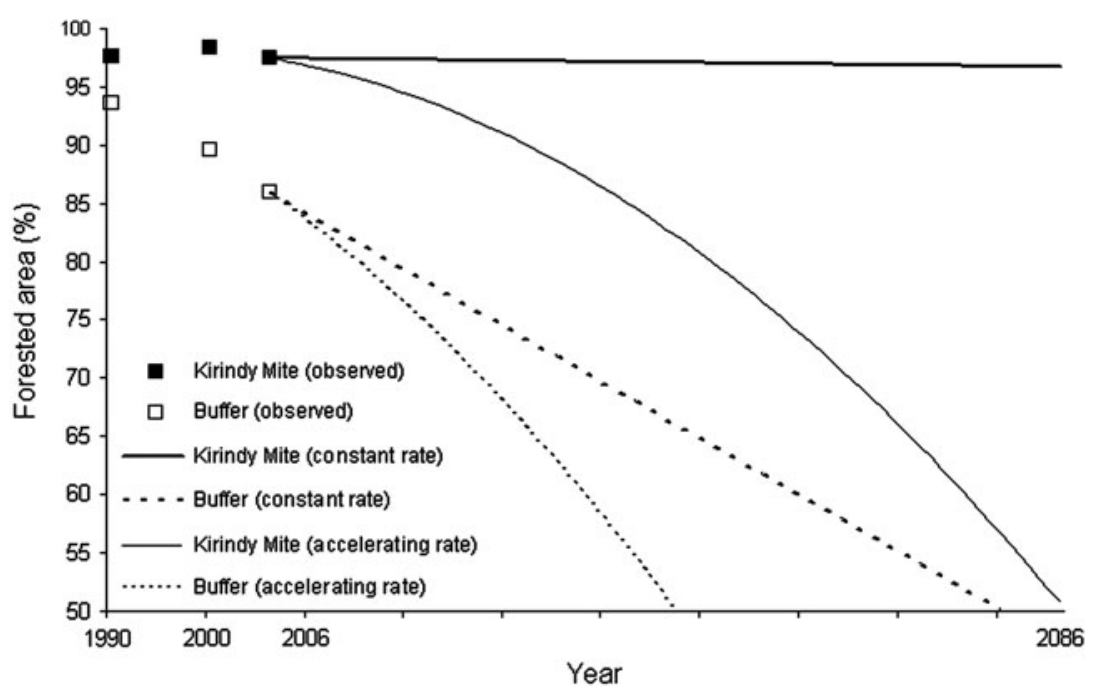

FIG. 4 Projected forest cover of Kirindy Mite National Park and an unprotected 5-km buffer under constant and accelerating net rates of forest-cover change. largest of the clearings are burn scars, evident in much of the study area and particularly in the south-east. The smaller clearings are more likely to be due to natural disturbances or small-scale, illegal harvest for fuel or for commercially valuable wood. The smallest anthropogenic disturbances are of single trees felled to collect wild honey but without detailed, in situ knowledge, these events are indiscernible from those of small lightning-ignited or other spot fires. Given their small size relative to the $30-\mathrm{m}$ resolution of Landsat images, most of the smallest events were undetectable with binary change detection methods but were apparent in sub-pixel analysis. This unique contribution of sub-pixel analysis calls for greater development and inclusion of sub-pixel methodologies in assisting land management.

No current remote sensing data or methods are available to discriminate primary from secondary forests with sufficient precision for model extrapolation over decadal time scales. This limits the conservation utility of remotely sensed studies because secondary forest cover does not immediately mitigate primary forest loss (Mayaux et al., 2005; Barlow et al., 2007b; Gardner et al., 2007). Secondary tropical forests support fewer plant and animal species than primary tropical forests (Aide et al., 2000; Barlow et al., 2007b; Gardner et al., 2007). However, secondary forests mitigate many other effects of primary forest degradation (Guariguata \& Ostertag, 2001; Barlow et al., 2007a). Secondary forests support species assemblages complementary to primary forests (Aide et al., 2000) and provide refugia for animal species after destruction of primary forest (Barlow et al., 2007a, 2007b; Gardner et al., 2007). Forest cover (whether primary or secondary) also reduces soil erosion (Costanza et al., 1997), an ecosystem service that is particularly important in western Madagascar, where intense rains (up to $1 \mathrm{~cm}$ minute ${ }^{-1}$ ) threaten thin, poorquality soils (Wells \& Andriamihaja, 1997).

Because of widespread disturbance and slow recovery rates, secondary forests will be an important component of
Madagascar's dry forests into the future. Natural recovery of deforested areas has been a successful restoration strategy in tropical forests elsewhere (Aide et al., 2000), and will be especially useful in and around Kirindy Mite National Park, where funding is limited. Because of their prevalence and different services compared to primary forest, greater attention should be paid to secondary forests in future conservation research and management, in addition to efforts to preserve existing primary forests.

\section{Management suggestions}

Most of the forest disturbances initiated in the unprotected buffer encroached minimally upon the Park, in many cases apparently stopping at or just inside the Park's boundary. However, as the difference in forest area between the Park and buffer widens, the deterrence of an unfortified boundary is likely to fade. The observed acceleration of deforestation, and probable cattle-driving inside the Park, may be indicators that this is already underway.

Although disturbances in the buffer seem to stop upon entering the Park, areas inside the Park near the northern and south-eastern boundaries have experienced the Park's most rapid and accelerated deforestation. This suggests that the conservation of the Park's forests relies both on their formal protected status as well as on the relative inaccessibility of the forest resources. To the degree that the latter is true, edge effects such as fire spread and cattle crossing the boundary would be reduced by decreasing the Park's ratio of perimeter to area, i.e. by expanding the Park to a simpler shape, particularly in the most vulnerable regions.

Expansion of the Park into lands traditionally used for resource extraction is unlikely to be supported by local communities without some form of compensation. However, if they were to perceive themselves as stakeholders and as beneficiaries of forest conservation they may work to 
protect the Park's forest resources (Liebenberg \& Grossman, 1994). Rather than employing direct payment as compensation, Park managers could develop alternatives to unsustainable extraction and work with the villages to manage the Park. Without reliance on subsidy or degradation, local economies may then shift from reliance on extraction to conservation, thus reducing anthropogenic pressure on the Park's forests.

Outside the Park, ANGAP should collaborate with communities to control fire. Currently fire within the Park is formally banned, although fire outside the Park is managed de facto by nomadic herdsmen burning after grazing an area. The resulting juxtaposition of fuel and ignition is likely to promote conflagrations inside the Park, especially as the Park's forests regrow (Dale, 2006). Lessons learned in dry forests and woodlands in temperate regions (e.g. chapparal, scrub, pine savannah) warrant caution in prolonged management of fire by suppression.

Conserving forest resources in the face of increasing human pressure is a challenging task, and maintaining the differences resulting from conserving forests on one side of the Park's boundary and extracting from them on the other will only become more difficult. As a more financially and politically efficient alternative to absolute expansion of the Park area, ANGAP could establish a buffer, similar to the one used in this study, as a transition zone where grazing and fire could be managed at sustainable levels. By softening the resource gradient at the Park's boundary, this strategy would potentially provide two benefits: (1) decreased contagion of disturbances, especially fire, into the Park, and (2) increase the perception of ANGAP as a benefactor to, and partner with, the surrounding communities.

\section{Conclusions}

Land cover changes in the dry deciduous forest in and around Kirindy Mite National Park have accelerated since 1990. Over the last 2 decades the Park has sustained less deforestation and experienced more reforestation of past disturbances within its boundaries compared to the area outside its boundaries. Although these trends do not discriminate between primary and secondary forest, the increase of overall forest cover is encouraging.

However, forest losses inside the Park have not completely ceased within the Park's interior. From 1990 to 2006 Park deforestation slightly exceeded reforestation as both processes accelerated. Park reforestation was offset by tree harvest, cattle-driving and uncontrolled anthropogenic fires invading the Park. Expansion of Kirindy Mite National Park was under consideration by ANGAP prior to this assessment. To continue protecting forest cover as the resource inequality across the Park boundary increases, we recommend that the ANGAP development plan include measures to: (1) expand the Park area to simplify its shape, (2) cooperate with the local communities in managing a buffer zone, and (3) increase monitoring to minimize trespass of anthropogenic disturbances into the Park. The results and recommendations presented here were delivered to ANGAP's Antananarivo headquarters and Morondava field office upon completion of this project. Since then the boundaries of Kirindy Mite National Park have been expanded substantially. Information from this study has and will be used in conjunction with other data to develop procedures to manage and preserve the remaining dry forest habitat within the boundaries of Kirindy Mite.

\section{Acknowledgements}

We thank the Morondava ANGAP office, the Département des Eaux et Forêts, the University of Anatananarivo (and especially Leon Pierrot Rahajanirina and Harilala Rakotomanana), the Institute for the Conservation of Tropical Environments, and the Madagascar Tripartite Committee for Scientific Research for guidance and logistical support over the duration of the project. We are very grateful to volunteers from Earthwatch and from Duke, Cambridge, and Cornell Universities for field work. We would like to thank Dr Stuart Pimm, Dr Clinton Jenkins, and the Conservation Ecology Lab as well as Dr Dean Urban and the Landscape Ecology Lab at Duke University for helpful editorial comments and generous technical expertise. Travel funds were provided by the Lazar Scholarship Fund for International Environmental Leadership through the Student International Discussion Group of Duke University.

\section{References}

Aide, T.M., Zimmerman, J.K., Pascarella, J.B., Riviera, L. \& MARCANO-VEGA, H. (2000) Forest regeneration in a chronosequence of tropical abandoned pastures: implications for restoration ecology. Restoration Ecology, 8, 328-338.

Barlow, J., Gardner, T.A., Araujo, I.S., Avila-Pires, T.C., Bonaldo, A.B., Costa, J.E. et al. (2007a) Quantifying the biodiversity value of tropical primary, secondary, and plantation forests. Proceedings of the National Academy of Sciences, 104, 18555-18560.

Barlow, J., Overal, W.L., Araujo, I.S., Gardner, T.A. \& Peres, C.A. (2007b) The value of primary, secondary, and plantation forests for fruit-feeding butterflies in the Brazilian Amazon. Journal of Applied Ecology, 44, 1101-1012.

Butler, R. (2005) Kirindy Mitea. Http://www.wildmadagascar.org/ conservation/parks/Kirindy_Mitea.html [accessed 30 September 2007].

Chander, M. \& Markham, B. (2003) Revised Landsat-5 TM radiometric calibration procedures and postcalibration dynamic ranges. IEEE Transactions on Geoscience and Remote Sensing, 41, 2674-2677.

Costanza, R., D’Arge, R., de Groot, R., Farber, S., Grasso, M., Hannon, B. et al. (1997) The value of the world's ecosystem services and natural capital. Nature, 387, 253-260.

DALE, L. (2006) Wildfire policy and fire use on public lands in the United States. Society and Natural Resources, 19, 275-284. 
Dollar, L.J. (2005) Carnivores of Madagascar: Expedition Briefing. Earthwatch Institute, London, UK.

Dollar, L.J. (2006) Morphometrics, diet, and conservation of Cryptoprocta ferox in Madagascar. PhD thesis, Duke University, Durham, USA.

Ganzhorn, J.U., Goodman, S.M., Ramanamanjanto, J.-B., Ralison, J., Rakotondravony, D. \& Rakotosamimanana, B. (2000) Effects of fragmentation and assessing minimum viable populations of lemurs in Madagascar. In Isolated Vertebrate Communities in the Tropics (ed. G. Rheinwald), pp. 265-272. Bonner Zoologische Monographien 46. Zoologisches Forschungsinstitut und Museum Alexander Koenig, Bonn, Germany.

Ganzhorn, J.U., Lowry, P.P., Schatz, G.E. \& Sommer, S. (2001) The biodiversity of Madagascar: one of the world's hottest hotspots on its way out. Oryx, 35, 346-348.

Gardner, T.A., Ribiero-Junior, M.A., Barlow, J., Avila Pires, T.C.S., Hoogmoed, M.S. \& Peres, C.A. (2007) The value of primary, secondary, and plantation forests for a neotropical herpetofauna. Conservation Biology, 21, 775-787.

GLCF (Global Land Cover Faciltty) (2006) Global Land Cover Facility. GLCF, University of Maryland, College Park, USA. Http://glcf. umiacs.umd.edu/index.shtml [accessed 12 December 2006].

GoOgle EarTh (2007) Google Earth. Http://www.earth.google.com [accessed 1 September 2007].

Green, G.M. \& Sussman, R.W. (1990) Deforestation history of the eastern rainforests of Madagascar from satellite images. Science, $248,212-215$.

Guariguata, M.R. \& Ostertag, R. (2001) Neotropical secondary forest succession: changes in structural and functional characteristics. Forest Ecology and Management, 148, 185-206.

Harper, G.J., Steininger, M.K., Tucker, C.J., Juhn, D. \& Hawkins, F. (2007) Fifty years of deforestation and forest fragmentation in Madagascar. Environmental Conservation, 34, 1-9.

Jenkins, M.D. (ed.) (1987) Madagascar: An Environmental Profile. IUCN, Gland, Switzerland, and Cambridge, UK.

Jensen, J.R. (1996) Introductory Digital Image Processing: A Remote Sensing Perspective (2nd edition). Prentice Hall, Upper Saddle River, USA.

Liebenberg, L. \& Grossman, D. (1994) Towards A New Nature Conservation Policy. Discussion Document for the Land and Agriculture Policy Center, Durban, South Africa.

Mayaux, P., Holgreen, P., Achard, F., Eva, H., Stibig, H. \& Branthomme, A. (2005) Tropical forest cover change in the 1990 s and options for future monitoring. Philosophical Transactions of the Royal Society B, 360, 373-384.

Myers, N., Mittermeier, R.A., Mittermeier, C.G., De FonsecA, G.A.B. \& Kent, J. (2000) Biodiversity hotspots for conservation priorities. Nature, 403, 853-858.

Ramanamanjato, J.B. (2000) Fragmentation effects on reptile and amphibian diversity in the littoral forest of southeastern Madagascar. In Isolated Vertebrate Communities in the Tropics (ed. G. Rheinwald), pp. 297-308. Bonner Zoologische Monographien 46. Zoologisches Forschungsinstitut und Museum Alexander Koenig, Bonn, Germany.

Ramanamanjato, J.-B. \& GanZhorn, J.U. (2001) Effects of forest fragmentation, introduced Rattus rattus and the role of exotic tree plantations and secondary vegetation for the conservation of an endemic rodent and a small lemur in littoral forests of southeastern Madagascar. Animal Conservation, 4, 175-183.

RAUH, W. (1979) Problems of biological conservation in Madagascar. In Plants and Islands (ed. D. Bramwell), pp. 405-421. Academic Press, London, UK.

Rouse, J.W., HaAs, R.H., Schell, J.A. \& Deering, D.W. (1974) Monitoring vegetation systems in the Great Plains with ERTS. In Third ERTS Symposium Volume I: Technical Presentations. NASA $S P-351$ (eds S.C. Freden, E. Nrico, P. Mercanti, M. Argaret \& A. Becker), pp. 309-317. NASA, Washington, DC, USA.

Song, C., Woods, C.E., Seto, K.C., Lenney, M.P. \& Macomber, S.A. (2001) Classification and change detection using Landsat TM data: when and how to correct atmospheric effects? Remote Sensing of Environment, 75, 230-244.

Sussman, R.W., Green, G.M. \& Sussman, L.K. (1994) Satellite imagery, human ecology, anthropology, and deforestation in Madagascar. Human Ecology, 22, 333-354.

Sussman, R.W., Richard, A.F. \& Ravelojaona, G. (1985) Madagascar: current projects and problems in conservation. Primate Conservation, 5, 53-59.

USGS (2007) US Geological Survey. Http://www.usgs.gov [accessed 10 January 2007].

Wells, N.A. \& Andriamihaja, B.R. (1997) Extreme gully erosion in Madagascar and its natural and anthropogenic causes. In Natural Change and Human Impact in Madagascar (eds S.M. Goodman \& B.D. Patterson), pp. 44-47. Smithsonian Institution Press, Washington, DC, USA.

Williams, D. (2007) NASA Landsat 7 Science Data Users Handbook. Http://landsathandbook.gsfc.nasa.gov/handbook/handbook_toc.html [accessed 5 January 2007].

WWF (2001) Madagascar Dry Deciduous Forests. Http:// www.worldwildlife.org/wildworld/profiles/terrestrial/at/ato202_ full.html [accessed 22 April 2007].

\section{Biographical sketches}

Amanda S. Whitehurst's research interests include conservation, land-cover change and ecosystem function, and remote sensing techniques. Joseph O. SEXton's research focuses on ecosystem services and land-cover dynamics in forested ecosystems. LUKE DOLLAR has conducted research, education, and outreach programmes on Madagascar biodiversity and conservation issues since 1994. His research focuses primarily on the carnivores, conservation and ecology of western Madagascar. 